\title{
PKLR NP_000289.1:p.R479H
}

National Cancer Institute

\section{Source}

National Cancer Institute. PKLR NP 000289.1:p.R479H. NCI Thesaurus. Code C158053.

A change in the amino acid residue at position 479 in the pyruvate kinase PKLR protein where arginine has been replaced by histidine. 